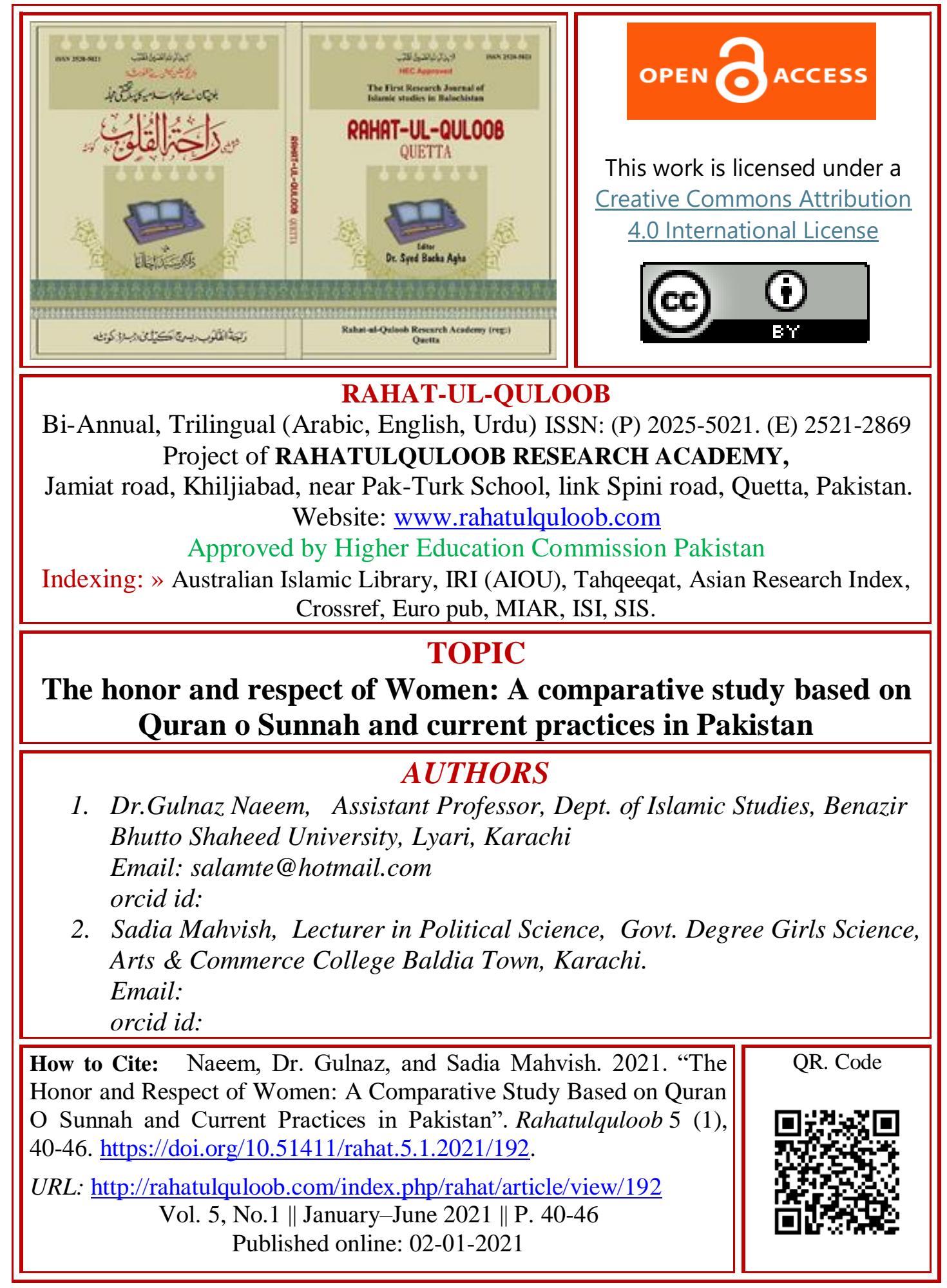




\title{
The honor and respect of Women: A comparative study based on Quran o Sunnah and current practices in Pakistan
}

\begin{abstract}
Islam honors both men and women and assigns several rights and duties on both of them. These rights and duties are based on their physique and nature for a proper family setup and peaceful society. In fact, it is the great initiative of Islam that it has banned female infanticide. Similarly, it is not important that Islam allows them to get education but it is their duty to get education. In addition, proper nourishment, health and security are among basic rights of women. Above all, she is the very first school to train and educate future's leaders. However, as the current practices of some Muslims are different from the glorious principles of Quran o Sunnah that's why there is doubt in some minds regarding the honor and respect of women in Islam. To clarify this doubt, there are several verses in Holy Quran which show their honor and dignity. Similarly, the sayings and practices of Prophet Muhammad (peace be upon him) are enough to respectfully deal with women either they are mothers, sisters, daughters or wives. The only issue is, to implement these injunctions and to practice them in the society.
\end{abstract}

${ }^{1}$ Gulnaz Naeem, ${ }^{2}$ Sadia Mahvish

Keywords: woman, honor, respect, rights, Islam, Pakistan.

\section{Introduction:}

Women play essential role in any society, their position and status cannot be compromised or neglected. That's why there is great concern and focus on women's position and status in the holy Quran. Similarly, the sayings and practices of Prophet Muhammad (peace be upon him) provide complete guidance to deal with women in decent way. While before the advent of Islam even the survival for female child was in danger. The birth of a female child was considered as a shameful act and they used to kill these innocent babies. Islam stopped this infanticide and made their parents liable for their proper nourishment, education and care. Similarly, women were granted the right of inheritance. However, they are not responsible for financial matters and to spend their money on household. Actually it's the responsibility of their father, husband or brother to provide them basic necessities. While women are free to spend their money and in case of absence of their guardians or any financial issue they are allowed to earn. Beside this, women were assigned several other rights based on their relationship such as mother, daughter or wife. In fact, they were granted the rights which can't be even imagine before the advent of Islam. Even to change the mindset of the people from female infanticide to their proper upbringing, Islamic teachings motivated them and mentioned different rewards for those parents and guardians who perform their children's rights properly.

On the other hand, the current practices are quite different with the matchless teachings of Islam. In some cases, women are facing domestic abuses, low or no 
access to get education, lack of health care and great sense of insecurity. Even sometimes they are killed in the name of honor killing. While in some cases by calling it equality, women are used as a tool to boost the business and economy and nothing else, and their dignity and respect becomes questionable. Unfortunately, such practices with women contributed nothing good in the society, where sometimes they are acting like a show piece and sometime they have no authority to deal with their own issues. It might be a reason that since several decades Muslim mothers couldn't train their offspring to be great leaders. The present era of Muslim world isn't glorious compare to their past. Surely, among some other reasons for the downfall of Muslims is also based on the scarcity of leadership in Muslim World.

\section{Women in Quran o Sunnah:}

Human beings are the decedents of same parents ${ }^{1}$ and Almighty Allah has honored them $^{2}$, no one is superior over other on the basis of race, gender, or ethnicity. While the most honored in the sight of Allah is the person who is the most righteous. ${ }^{3}$ There are many verses in Holy Quran where men and women are equally treated. For example: Allah will reward all those who are Muslim, believing, obedient, truthful, patient, humble, charitable, fasting, guard their private parts and remember $\mathrm{Him}^{4}$ (either male or female). For their righteous deeds they would be entered in Paradise ${ }^{5}$ and in this world they would also live a good life. ${ }^{6}$ Even the respect and honor of women is guarded by assigning their responsibility to men in following words: 'Men are the protectors and maintainers of women, because Allah has made one of them to excel the other, and because they spend (to support them) from their means. ${ }^{7}$ On contrary, if wife spend on her poor husband then she will be rewarded twice. It is mentioned in 'Sunnan Ibn Majah' that once a lady asked the Prophet (PBUH): 'Will it be accepted as charity on my part if I spend on my husband and the orphans in my care?' then the Prophet (PBUH) replied: 'She will have two rewards, the reward for charity and the reward for upholding ties of kinship. ${ }^{8}$ However, this spending on her husband doesn't mean disobedience of her husband. Because, there is another saying of Prophet (PBUH) that if a woman is regular in her prayers and fasts, guards her chastity and obeys her husband then she will be asked to enter any of the doors of the paradise. ${ }^{9}$

There is some difference in the role of man and woman and it creates a balance in the society. While there is no difference in the material of their creation as mentioned in Holy Quran, 'man is created from a single being and its mate is created out of it.' 10 Another verse says that their mates are from their selves ${ }^{11}$. About their role Almighty Allah says, 'O you who have believed, protect yourselves and your families from a Fire.' ${ }^{12}$ Similarly, the Prophet Muhammad (pbuh) said, 'woman is a guardian over the household of her husband and his children; and she will be questioned about them.' ${ }^{13}$ This guardianship itself is a great honor for a Muslim woman. That's why the Prophet Muhammad (pbuh) ranked a mother three degrees higher than a father ${ }^{14}$ and forbidden the children to be undutiful to their mothers. ${ }^{15}$ Moreover, once the Prophet Muhammad 
(pbuh) refused a man's wish for taking part in Jihad and asked him to stay with his mother, for Paradise is at her feet ${ }^{16}$ and also said that Almighty Allah has forbidden people to be undutiful to their mothers ${ }^{17}$. In fact, Prophet of Islam (peace be upon him) instructs it followers to fairly deal with females. The very first right of a woman which Islam has been assigned to them is their birth. The Prophet (peace be upon him) forbade people from infanticide of daughters ${ }^{18}$. About the proper education and their training he (peace be upon him) said: If someone has 3 or 2 daughters/sisters and he keeps good company with them and having Allah's fears regarding them, will be entered in Paradise ${ }^{19}$. There might be some difficulties in their upbringing, therefore, if someone tried with anything from his daughters, and shows patient over it then these daughters will be a fence from the hellfire for him $^{20}$. The Prophet (peace be upon him) also instructed people to marry their daughters ${ }^{21}$ and even orphan girls with their permission ${ }^{22}$. She also has a right to cancel her marriage if she doesn't like or if it was forceful one ${ }^{23}$. He (peace be upon him) also advised to take care of the women ${ }^{24}$ and forbade them to treat their wives as slaves ${ }^{25}$.

These commandments in Quran o Sunnah clearly reveal that both men and women are equally rewarded by Allah Almighty in their efforts and religious obligations. Almighty Allah had honored the children of Adam without any gander discrimination. Rather than mentioning superiority because of being man, Allah Almighty had set the criteria of righteousness by saying 'the most noble is the most righteous in the sight of Almighty'. So, among men and women however is the righteous will be honorable in sight of Almighty Allah. If believing women are instructed to be modest (Haya) and not allowed to expose their adornment ${ }^{26}$ then before this instruction believing men are asked to lower their gaze ${ }^{27}$. If men are mentioned as 'Qawwam' (the maintainers and protectors of women) then 'the girl buried alive' will be questioned, what was her crime? See, if the pagan Arab of pre Islamic era will be questioned for their deeds then definitely those so-called Mulims will also be questioned who tease their girls/women by practicing the customs of 'honor killing', 'watta satta', 'Vani' or any form of women's violation. On the other hand, to change the mindset of people the Prophet (peace be upon him) said, for him women and perfumes are among the most likely worldly things and his comfort is in prayers ${ }^{28}$. Similarly by highlighting the importance of women and for grooming the personality of women, he (peace be upon him) said, among the women of the world four women are sufficient for you (to follow) i.e.

i. $\quad$ Mariam bint-e-Imran (Mary the mother of Jesus peace be upon him)

ii. Khadijah bint Khuwailid (the wife of Prophet peace be upon him)

iii. Fatimah bint-e-Muhammad (peace be upon him) and

iv. Asiyah the wife of Fir'awn ${ }^{29}$

\section{Current practices in Pakistan:}

The respect and honor for women in Islam is quite obvious in the teachings of Quran o Sunnah. But when we talk about Pakistan, we don't see such an ideal position of 
women which is discussed in Quran o Sunnah. In fact, the respect and honor of women is bond with several rights and duties and problem creates when either men or women talk about their rights without fulfilling their duties. Apart from these glorious teachings of Islam, people are very much influenced through their culture. In Pakistani society there are several cultures and tradition which is also a big cause of violation in women's rights. Such as: restriction in providing education, poor or no health care, no share from inheritance, honor killing, watta satta, early and forceful marriages etc. Among these crimes some are briefly mentioned here.

\section{a. Domestic violence and abuse:}

This one is the most common form of violence and can be of any form based on psychological or physical torture. Even sometimes they face acid attacks, bursting stove, murder on the name of suicide and different planned accidents. Usually they face this violence and discrimination on daily basis. According to an estimate 70 to $90 \%$ Pakistani women are its victim ${ }^{30}$. However, the facts and figures vary based on the cultural norms and rural or urban areas. Moreover, there isn't any record of many of such violence or abuses because of their family norms, women dislike to disclose these issues.

\section{b. Honor Killing:}

It is an extreme form of violence, practiced in the rural and tribal areas of Pakistan ${ }^{31}$ to punish any man or woman for humiliating the family honor by means of any illicit relation or disobedience of family for marriage. However, many of its victims are women. The concept of honor killing can be traced in the pre-Islamic Arabia, and goes back to antiquated Roman $\mathrm{era}^{32}$. On an average, at least 3 women per day including victims of rape are reported killed in the name of so-called family honor ${ }^{33}$. They are usually killed by close relatives, mostly spouse, father or brother ${ }^{34}$.

\section{c. Watta Satta:}

In some rural and tribal areas marriages named as 'watta satta' which is an exchange of bride for another bride. It is not necessary to arrange both marriages on the same time but one party marries her daughter and second party's daughter becomes reserve for any male of the first party. This is not only experienced in lower class but middle and even upper class are also involved in this violence against women ${ }^{35}$. The worst situation of 'watta satta' is, newly born babies or not even born ${ }^{36}$ are exchanged in this custom.

\section{d. Dowry:}

In some of the Pakistani cultures, honor and respect of a bride depends on the quantity and quality of the dowry and sometime on the amount paid instead of dowry. That's why dowry seems as a cause of conflict and greed in the society ${ }^{37}$. Although, such luxurious and extravagant marriages are against the basic spirit and soul of the Islamic family system but it has become a mandatory norm on the society, just because of the cultural influence from the non-Muslim communities of the Subcontinent. 


\section{e. Violation in the Right of Inheritance:}

It's the specification of Islam that it gives the right of inheritance to women. They get the prescribed share from the property of their fathers and husbands but Pakistani women are deprived in getting their share. They are forced and compelled to surrender their right for their brothers or any male member of the family. Sometimes all the efforts of the women to get this right go in vain and they get nothing even after knocking the door of the court. One of such victims is, Akhtari Begum from Khaniwal who was brutally tortured by his brothers ${ }^{38}$. It's not only the family matter but the policy processes involved in providing the right of inheritance to the women couldn't address successfully through any government ${ }^{39}$.

\section{Conclusion:}

Islam honors both men and women and assigns several rights and duties on both of them for a proper family setup based on their physique and nature. However, as the current practices in Pakistan based on various cultures and norms are different from the glorious principles of Quran o Sunnah that's why there is doubt in some minds regarding the honor and respect of women in Islam. In order to clarify this doubt, there are several verses in Holy Quran which show their honor and dignity. Similarly, the sayings and practices of Prophet Muhammad (peace be upon him) are enough to respectfully deal with them. The only issue is, to implement these injunctions and practices in our lives. Therefore, in order to build the true image of Islam regarding women's honor and respect, Muslims need to implement these teachings. In Pakistan, there might be proper legislation for the sake of women's honor and dignity with its solid implementation. Because being a Muslim country, whatever issue raised here in Pakistan, is highlighted internationally as Islamic or Muslim issue. Therefore, it will also be a remarkable contribution in exposing the true image of Islam.

\section{Referances:}

${ }^{1}$ A-Nisa4:1

${ }^{2}$ Al-Isra17:70

${ }^{3}$ Al-Hujraat49:13

${ }^{4} \mathrm{Al}-$ Ahzab33:35

${ }^{5}$ A-Nisa4:124

${ }^{6} \mathrm{Al}-\mathrm{Nah} 116: 97$

${ }^{7}$ A-Nisa 4:34

${ }^{8}$ Sunan Ibn Majah, Chapter: Regarding Zakat, Hadith No. 52

${ }^{9}$ Musnad Imam Ahmad Bin Hanbal, Hadith No. 1661

${ }^{10}$ A-Nisa4:1

${ }^{11} \mathrm{Al}-\mathrm{Shuraa} 42: 11$

${ }^{12}$ Surah Tahrim 66, Verse 6

${ }^{13}$ Sahih Muslim, The Book on Government, Hadith No. 24

${ }^{14}$ Sunan Ibn Majah, Chapters: on Wills, Hadith No. 2810

${ }^{15}$ Sahih al-Bukhari, Book of Good Manners and Form (Al-Adab), Hadith No. 6

${ }^{16}$ Sunan an-Nasa'i, The Book of Jihad, Hadith No. 3104 
${ }^{17}$ Sahih Bukhari, Book of Good Manners and Form (Al-Adab), Hadith No. 5975

${ }^{18}$ Ibid

${ }^{19}$ Jami at-Tirmidhi, Chapter: What Has Been Related About Spending on Daughters And Sisters, Hadith No. 1915

${ }^{20}$ Jami at-Tirmidhi, Chapter: What Has Been Related About Spending on Daughters And Sisters, Hadith No. 1913

${ }^{21}$ Sunan Abi Dawud, Kitab Al-Nikah, Chapter: Seeking The Girl's Permission, Hadith No. 2092

22 Sunan Abi Dawud, Kitab Al-Nikah, Chapter: Regarding Widowed \& Divorced Women, Hadith No. 2100

${ }^{23}$ Sahih al-Bukhari, Book of Tricks, Hadith No. 6969

${ }^{24}$ Sahih al-Bukhari, Book of Nikaah, Hadith No. 5185-86

${ }^{25}$ Sahih al-Bukhari, Book of Nikaah, Hadith No.5204

${ }^{26} \mathrm{Al}-\mathrm{Nur} 24: 31$

${ }^{27} \mathrm{Al}-\mathrm{Nur} 24: 30$

${ }^{28}$ Al-Nasa'i, The Book of the kind Treatment of women, Hadith No. 3939

${ }^{29}$ Jami` at-Tirmidhi, Chapters on virtues, Hadith No. 3878

${ }^{30}$ Ali, Parveen A and Gavino, Maria I B. "Violence against Women in Pakistan: A framework for Analysis.” Journal of Pakistan Medical Association, 58(4), 2008, 198-203

${ }^{31}$ Malik, Amar H. "Honour Killing in Pakistan." SSRN Electronic Journal, 2014. doi:10.2139/ssrn.2411680.

${ }^{32}$ Lari, Maliha Z. A Pilot Study on Honour Killings' in Pakistan and Compliance of Law. Aurat Publication and Information Service Foundation 2011. p.18

${ }^{33}$ Malik, Amar H. "Honour Killing in Pakistan." SSRN Electronic Journal, 2014

${ }^{34}$ Knudsen, Are J. License to Kill: Honour Killings in Pakistan. 2004.

${ }^{35}$ Khoso, Immamuddin, Kamran Shafiq, Asad R. Abdi, and Faiz. M. Shaikih. "Problems and Challenges Faced by the Rural Women: A Case Study of Balochistan." Asian Culture and History 3, no. 1 (2011)

36 Jacoby, Hanan G., and Ghazala Mansuri. "Watta Satta: Bride Exchange and Women's Welfare in Rural Pakistan." American Economic Review 100, no. 4 (2010), 1804-1825

${ }^{37}$ Gulzar, Sadia. Nauman, Muhammad. Yahya, Farzana. Ali, Shagafat, and Yaqoob Mariam. "Dowry System in Pakistan." Asian Economic and Financial Review. 2 no.7 (2012). 784-94

${ }^{38} \mathrm{https}: / /$ www.bbc.com/urdu/pakistan-43976080

39 Butt, Beenish I, and Asad, Amir Z "Refutation, Relinquishment and Inheritance: Exploring Women's Inheritance Rights in Pakistan.” Pakistan Journal of Social Sciences. 36 no. 2 (2016). 1001-1009 